Materiales de Construcción

Vol. 67, Issue 328, October-December 2017, e140

ISSN-L: 0465-2746

http://dx.doi.org/10.3989/mc.2017.10816

\title{
Preparation of $\beta$-belite using liquid alkali silicates
}

\author{
P. Koutník \\ Unipetrol Centre for Research and Education, (Ústí nad Labem, Czech Republic) \\ $\triangle$ petr.koutnik@unicre.cz
}

\author{
Received 19 September 2016 \\ Accepted 7 February 2017 \\ Available on line 19 October 2017
}

\begin{abstract}
The aim of this study is the preparation of $\beta$-belite by a solid-state reaction using powdered limestone, amorphous silica and liquid alkali silicates. The raw materials were blended, the mixtures were agglomerated and then burnt. The resulting samples were characterized by X-ray diffraction analysis and scanning electron microscopy. Free lime content in the $\beta$-belite samples was also determined. The effects of $\mathrm{CaO} / \mathrm{SiO}_{2}$ ratio (1.6-2.1), burning temperature $\left(800-1400^{\circ} \mathrm{C}\right.$ ), utilization of different raw materials (silica fume, synthetic silica, potassium silicate, sodium silicate, potassium hydroxide) and burning time $(0.5-16 \mathrm{~h})$ on free lime content and mineralogical composition were investigated. The purest $\beta$-belite samples were prepared from a mixture of powdered limestone, silica fume and liquid potassium silicate with a ratio $\mathrm{CaO} / \mathrm{SiO}_{2}=2$ by burning at temperatures between 1100 and $1300{ }^{\circ} \mathrm{C}$ for more than $2 \mathrm{~h}$. Decreasing of the $\mathrm{CaO} / \mathrm{SiO}_{2}$ ratio led to rankinite formation and lower a burning temperature led to the formation of wollastonite.
\end{abstract}

KEYWORDS: Dicalcium silicate; Alkali; Silica Fume; Limestone; X-ray Diffraction (XRD)

Citation/Citar como: Koutník, P. (2017) Preparation of $\beta$-belite using liquid alkali silicates. Mater. Construcc. 67 [328], e140. http://dx.doi.org/10.3989/mc.2017.10816

RESUMEN: Preparación de $\beta$-belita usando silicatos alcalinos líquidos. El objetivo de este estudio ha sido la preparación de $\beta$-belita por reacción en estado sólido usando caliza, sílice amorfa y silicatos alcalinos líquidos. Las materias primas se mezclaron y posteriormente, se aglomeraron y calcinaron. Los productos se caracterizaron mediante difracción de rayos $\mathrm{X}$ y microscopía electrónica de barrido. Se determinó el contenido de cal libre en la $\beta$-belita. Se ha estudiado el efecto de la relación $\mathrm{CaO} / \mathrm{SiO}_{2}$ (1.6-2.1), temperatura de combustión $\left(800-1400{ }^{\circ} \mathrm{C}\right)$, utilización de diferentes materias primas y el tiempo de combustión sobre el contenido de cal libre en el producto. La $\beta$-belita más pura se preparó a partir de la mezcla de piedra caliza en polvo, humo de sílice y silicato de potasio líquido con relación $\mathrm{CaO} / \mathrm{SiO}_{2}=2$ a temperaturas entre 1100 y $1300^{\circ} \mathrm{C}$ durante más de 2 horas. La disminución de la relación $\mathrm{CaO} / \mathrm{SiO}_{2}$ produjo rankinita y una temperatura de combustión más baja produjo wollastonita.

PALABRAS CLAVE: Silicato bicálcico; Álcalis; Humo de sílice; Caliza; Difracción de rayos X (DRX)

ORCID ID: P. Koutník (http://orcid.org/0000-0002-3486-5577)

Copyright: (C) 2017 CSIC. This is an open-access article distributed under the terms of the Creative Commons Attribution License (CC BY) Spain 3.0.

\section{INTRODUCTION}

Cement production is associated with high energy consumption and $\mathrm{CO}_{2}$ emissions, therefore the cement industry is facing challenges to reduce them. One of the routes is the manufacturing of clinkers based on dicalcium silicate $\left(\mathrm{C}_{2} \mathrm{~S}\right.$-belite $)$.
Belite formation generates reduced amounts of $\mathrm{CO}_{2}$ and also energy consumption is lower in comparison with tricalcium silicate $\left(\mathrm{C}_{3} \mathrm{~S}-\right.$ alite $)$, the main component of Portland cement $(1,2)$.

Dicalcium silicate exists in several polymorphic forms at ordinary pressures: $\alpha, \alpha_{\mathrm{H}}^{\prime}, \alpha_{\mathrm{L}}^{\prime}, \beta$ and $\gamma$ (3). The $\gamma$ form is thermodynamically stable at room 
temperature, but it has a lower degree of hydraulicity than the other forms. $\alpha, \alpha_{H}^{\prime}, \alpha_{L}^{\prime}$ and $\beta$ forms are not stable in the pure state at room temperature $(4,5)$. Chemical stabilization of these reactive belite forms can be carried out by the addition of many elements $(\mathrm{K}, \mathrm{Na}, \mathrm{Fe}, \mathrm{Mg}, \mathrm{S}, \mathrm{Ba})$ in various compounds, e.g. $\mathrm{BaCl}_{2}, \mathrm{Na}_{2} \mathrm{SO}_{4}, \mathrm{NaF}, \mathrm{K}_{2} \mathrm{CO}_{3}, \mathrm{Na}_{2} \mathrm{CO}_{3}$, $\mathrm{FeSO}_{4}(3,5,6-11)$. Stabilization of the reactive belite structure was also achieved by the rapid cooling of clinker $(3,8)$.

Although $\beta$-belite hydratation is much slower than that of alite, the later strength of the belite-rich and alite-rich cement pastes can be similar $(3,12)$. Lower reactivity of belite is enhanced by the production of belite-rich cements, also containing other hydraulic phases and/or pozzolans. Belite sulfoaluminate cements and belite sulfoferroaluminate cements can contain whichever of the phases $\mathrm{C}_{2} \mathrm{~S}, \mathrm{C}_{12} \mathrm{~A}_{7}, \mathrm{CA}$, $\mathrm{C}_{2} \mathrm{~A}_{3} \mathrm{~S}, \mathrm{C}_{4} \mathrm{~A}_{3} \mathrm{~S}, \mathrm{C}_{4} \mathrm{AF}, \mathrm{CS}$, depending on clinker chemical composition (3,12-16). Roman cements, key building material in the nineteenth century, are produced by burning of limestones rich in clay minerals, below their sintering point. Mineralogical compositions of Roman cements are variable, strongly depending on raw material composition. Roman cements typically contain phases $\mathrm{C}_{2} \mathrm{~S}$, quartz, free lime and amorphous aluminosilicates. Other phases can be $\mathrm{CS}, \mathrm{C}_{3} \mathrm{~S}_{2}, \mathrm{C}_{3} \mathrm{~A}$, $\mathrm{C}_{2} \mathrm{AS}$ and $\mathrm{C}_{4} \mathrm{AF} ; \mathrm{C}_{3} \mathrm{~S}$ is excluded because of the low temperature during burning. Currently, Roman cements are especially manufactured for repairing historical monuments (17-21).

Several methods of the preparation of belite cement or pure belite have been studied closely in laboratory scale. The most common process, corresponding to industrial production, involves the blending of powdered raw materials eventually followed by agglomeration, and final burning of the mixture $(8,12,22-25)$. Better homogenization can be achieved by dispergation of the raw materials in water or ethanol $(5,9-11)$, especially under ultrasound treatment $(6,26)$. A hydrothermal method for belite cement or pure belite preparation is more sophisticated and is also often applied. This method is based on hydrothermal synthesis of hydrated precursors (one or more items among $\mathrm{C}_{2} \mathrm{SH}, \mathrm{CSH}$, $\mathrm{C}_{3} \mathrm{ASH}_{4}$ etc.) and on their subsequent burning $(1,7,9,27-36)$. The described conditions of hydrothermal synthesis (temperature, pressure and time) are various; extending from ambient temperature and pressure and a long time (up to one month)
(7) to high pressure and high temperature at short times $\left(17 \mathrm{bar}, 250^{\circ} \mathrm{C}, 4 \mathrm{~h}\right)(28)$. The hydrothermal process can be carried out not only in water but also in alkaline solutions $(\mathrm{NaOH}, \mathrm{KOH})(1,9,31,36)$. Other methods for pure belite preparation are based on a sol-gel process, using calcium nitrate tetrahydrate and silica sol to produce gel. The gel is dried and calcined (37-43). Zeng (44) prepared belite by the co-precipitation of calcium silicate in $\mathrm{CaCl}_{2}-$ $\mathrm{Na}_{2} \mathrm{SiO}_{3}-\mathrm{NaOH}$ solutions and subsequent calcination of the formed hydrated precursor.

The present work is focused on the preparation of $\beta$-belite by a solid-state reaction, using raw materials produced in high volumes in industrial scale: powdered limestone, amorphous silica and liquid alkali silicates (water glasses). These alkali silicates were used here for their ability to bind effectively powdered raw materials, and as a natural source of reactive $\mathrm{SiO}_{2}$ and of alkali ions, the latter having been reported as $\beta$-belite structure stabilizers. Systematic investigation was carried out to determine the influence of $\mathrm{C} / \mathrm{S}$ ratio, reaction temperature and the sort of silica and alkali ions used on phase composition and free lime content.

\section{MATERIALS AND METHODS}

\subsection{Materials}

The raw materials used for dicalcium silicate preparation were partly powdered, such as synthetic silica (VP4; AV EKO-COLOR, s.r.o., Czech Republic), silica fume (České lupkové závody, a.s., Czech Republic) and limestone (Omyacarb 5VA; Omya), partly liquid, such as potassium silicate (Z. Ch. Rudniki S.A., Poland) and sodium silicate (Vodní sklo, a.s., Czech Republic).

The chemical compositions of powdered raw materials, determined by X-ray fluorescence, are presented in Table 1. The specific surface area obtained by the BET method, specific gravity and bulk density of powdered raw materials are shown

TABLE 2. Physical properties of powdered raw materials

\begin{tabular}{lccc}
\hline & $\begin{array}{c}\text { BET } \\
\left(\mathbf{m}^{\mathbf{2}} \mathbf{g}\right)\end{array}$ & $\begin{array}{c}\text { Specific gravity } \\
\left(\mathbf{k g} / \mathbf{m}^{3}\right)\end{array}$ & $\begin{array}{c}\text { Bulk density } \\
\left(\mathbf{k g} / \mathbf{m}^{3}\right)\end{array}$ \\
\hline Limestone & 6.77 & 2658 & 787 \\
Silica fume & 15.32 & 2204 & 303 \\
Synthetic silica & 142.4 & 2111 & 174 \\
\hline
\end{tabular}

TABLE 1. Chemical composition (wt. \%) of powdered raw materials

\begin{tabular}{lccccccccccccc}
\hline & $\mathbf{L O I}^{\mathrm{a}}$ & $\mathbf{S i O}_{2}$ & $\mathbf{A l}_{2} \mathbf{O}_{3}$ & $\mathbf{F e}_{2} \mathbf{O}_{3}$ & $\mathbf{C a O}$ & $\mathbf{M g O}$ & $\mathbf{K}_{2} \mathbf{O}$ & $\mathbf{N a}_{2} \mathbf{O}$ & $\mathbf{T i O}_{2}$ & $\mathbf{P}_{2} \mathbf{O}_{5}$ & $\mathbf{Z r O}_{2}$ & $\mathbf{C l}$ & $\mathbf{S O}_{3}$ \\
\hline Limestone & 43.7 & 0.50 & 0.27 & - & 55.1 & 0.41 & - & - & - & - & - & - & - \\
Silica fume & 0.68 & 95.6 & 0.23 & 0.30 & 1.34 & - & - & - & - & 0.44 & 1.14 & - & 0.11 \\
Synthetic silica & 4.23 & 92.3 & 0.22 & 0.06 & 0.16 & 2.14 & 0.01 & 0.47 & 0.06 & - & - & 0.02 & 0.38 \\
\hline
\end{tabular}

${ }^{\mathrm{a}} \mathrm{LOI}=$ Loss on ignition 


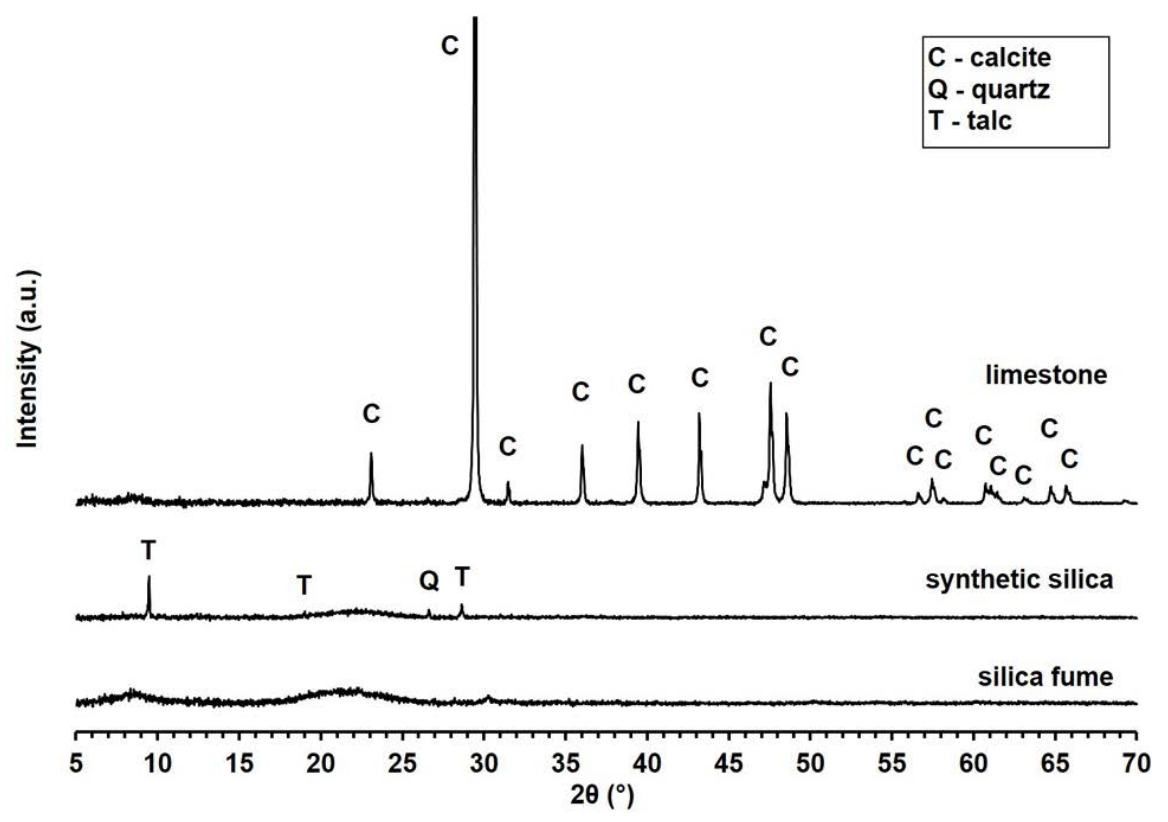

FIGURE 1. XRD patterns of powdered raw materials.

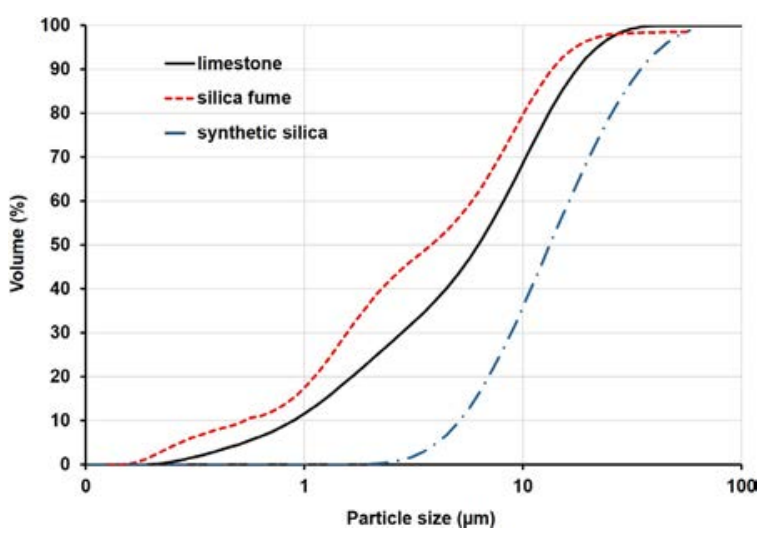

FIGURE 2. Particle size distributions of powdered raw materials.

in Table 2. The mineralogical compositions are given in XRD patterns in Figure 1. Particle size distributions are shown in Figure 2 and pore size distributions in Figure 3. The chemical compositions of liquid alkali silicates are presented in Table 3.

Analytical grade potassium hydroxide (Lachner) and distilled water were used to prepare a $25 \% \mathrm{KOH}$ solution.

\subsection{Analytical and testing methods}

The chemical compositions of powdered raw materials were determined by X-ray fluorescence (BRUKER S8 Tiger).

A BRUKER D8 Advanced X-Ray diffraction system (XRD) equipped with BRUKER SSD 160 detector and operating with $\mathrm{Cu}-\mathrm{K} \alpha$ radiation at

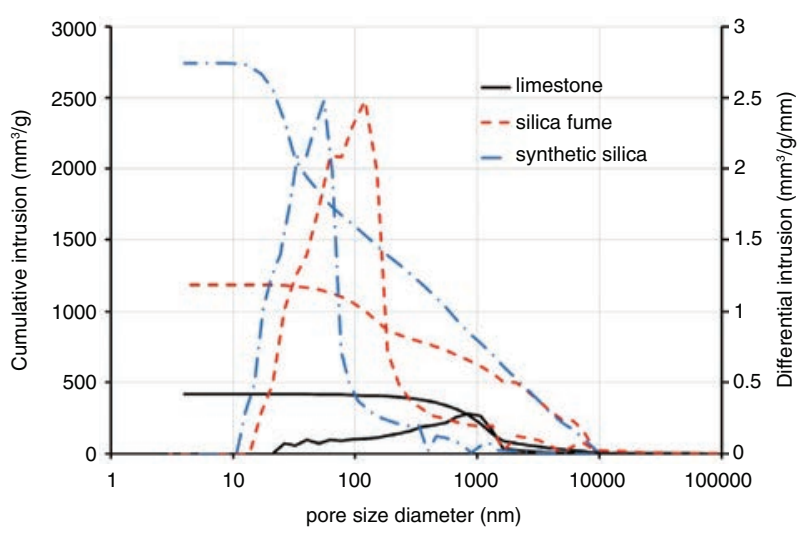

FIgURE 3. Pore size distributions of powdered raw materials.

TABLE 3. Chemical composition (wt. \%) of liquid alkali silicates

\begin{tabular}{lccccc}
\hline & $\mathbf{H}_{2} \mathbf{O}$ & $\mathbf{S i O}_{2}$ & $\mathbf{A l}_{2} \mathbf{O}_{3}$ & $\mathbf{K}_{2} \mathbf{O}$ & $\mathbf{N a}_{2} \mathbf{O}$ \\
\hline Potassium silicate & 69.02 & 21.29 & 0.03 & 8.18 & 0.70 \\
Sodium silicate & 64.59 & 22.59 & 0.07 & 0.26 & 12.75 \\
\hline
\end{tabular}

$40 \mathrm{kV}$ and $25 \mathrm{~mA}$ was used for analysis of raw materials and prepared dicalcium silicates. XRD scanning was taken at the $2 \theta=0.02$ step over an angular range from $5^{\circ}$ to $70^{\circ}$ with $1 \mathrm{~s}$ counting time.

A Mastersizer 2000 laser diffraction particle size analyser (MALVERN Instruments) was used to determine size distribution of powdered raw materials. Agglomerates were disrupted by ultrasound treatment. 
TABLE 4. Compositions of raw materials mixtures (wt. \%)

\begin{tabular}{lcccccccccc}
\hline Raw material & M1 & M2 & M3 & M4 & M5 & M6 & M7 & M8 & M9 & M10 \\
\hline Limestone & 58.73 & 59.73 & 60.65 & 61.49 & 62.27 & 62.99 & 61.54 & 62.53 & 69.49 & 68.37 \\
Silica fume & 17.27 & 16.27 & 15.35 & 14.51 & 13.73 & 13.01 & - & 13.48 & 21.36 & 21.02 \\
Potassium silicate & 24.00 & 24.00 & 24.00 & 24.00 & 24.00 & 24.00 & 24.00 & - & - & - \\
Synthetic silica & - & - & - & - & - & - & 14.46 & - & - & - \\
Sodium silicate & - & - & - & - & - & - & - & 24.00 & - & - \\
$\mathrm{H}_{2} \mathrm{O}$ & - & - & - & - & - & - & - & - & 9.14 & - \\
$\mathrm{KOH}-25 \%$ solution & - & - & - & - & - & - & - & - & - & 10.61 \\
$\mathrm{CaO} / \mathrm{SiO}_{2}(\mathrm{~mol} / \mathrm{mol})$ & 1.60 & 1.70 & 1.80 & 1.90 & 2.00 & 2.10 & 2.00 & 2.00 & 2.00 & 2.00 \\
\hline
\end{tabular}

Pore size distributions of powdered raw materials were determined using AutoPore 9510 mercury intrusion porosimeter (Micromeritics), which operates with pressures from $0.01 \mathrm{MPa}$ to $414 \mathrm{MPa}$.

A gas sorption analyser Autosorb iQ from Quantachrome was used for the determination of specific surface area by the Brunauer-Emmett-Teller method (BET).

Free lime content in dicalcium silicate samples was determined by a glycerine-alcohol test.

The morphology of silica fume and synthetic silica was studied by a scanning electron microscope Mira 3 from (TESCAN).

An inductively coupled plasma optical emission spectrometer OPTIMA 8000 (Perkin Elmer) was used to determine the content of micro-elements and $\mathrm{K} / \mathrm{Na}$ ratio in liquid alkali silicates. Total content of alkali metals $(\mathrm{Na}, \mathrm{K})$ and content of $\mathrm{SiO}_{2}$ in alkali silicates were determined by conventional acid-base titration methods; the reason for their application being higher accuracy at higher concentrations compared with other methods.

Specific gravity was determined by the pycnometric method.

\subsection{Procedure}

Ten mixtures M1-M10 were prepared by hand stirring in a vessel. Compositions of these mixtures, which are given in Table 4, were determined by calculation according to the required $\mathrm{C} / \mathrm{S}$ ratios. The M8 mixture was a plastic material that was divided into amounts of about $20 \mathrm{~g}$ and dried at $120^{\circ} \mathrm{C}$. The others mixtures were compacted into tablets (diameter $40 \mathrm{~mm}$, weight $20 \mathrm{~g}$ ) under $20 \mathrm{kN}$ using a hydraulic press. All agglomerated mixtures were burnt at a designed temperature in an electric muffle furnace for the required time, and then allowed to cool very slowly (overnight) inside the furnace. The heating rates were the maximum possible, which comprised the interval $8-12{ }^{\circ} \mathrm{C} / \mathrm{min}$. Twenty $\beta$-belite samples B1-B20 were obtained under the conditions shown in Table 5. Chemical compositions of the $\beta$-belite samples were found out by the calculation are given in Table 6.
TABLE 5. Conditions of $\beta$-belite preparation

\begin{tabular}{|c|c|c|c|c|}
\hline Sample & Mixture & Agglomerates & $\begin{array}{c}\text { Burning } \\
\text { temperature } \\
\left({ }^{\circ} \mathrm{C}\right)\end{array}$ & $\begin{array}{c}\text { Burning } \\
\text { time } \\
\text { (h) }\end{array}$ \\
\hline B1 & M1 & \multirow{6}{*}{ Tablets } & \multirow{6}{*}{1100} & \multirow{6}{*}{8} \\
\hline B2 & M2 & & & \\
\hline B3 & M3 & & & \\
\hline B4 & M4 & & & \\
\hline B5 & M5 & & & \\
\hline B6 & M6 & & & \\
\hline B7 & & & 800 & \\
\hline B8 & & & 950 & \\
\hline B9 & M5 & Tablets & 1250 & 8 \\
\hline B10 & & & 1300 & \\
\hline B11 & & & 1400 & \\
\hline B12 & M7 & Tablets & & \\
\hline B13 & M8 & $\begin{array}{l}\text { Plastic } \\
\text { material }\end{array}$ & 1100 & 8 \\
\hline B14 & M9 & Tablets & & \\
\hline B15 & M10 & Tablets & & \\
\hline B16 & & & & 0.5 \\
\hline B17 & & & & 1 \\
\hline B18 & M5 & Tablets & 1100 & 2 \\
\hline B19 & & & & 4 \\
\hline B20 & & & & 16 \\
\hline
\end{tabular}

\section{RESULTS AND DISCUSSION}

\subsection{Effect of $\mathrm{CaO} / \mathrm{SiO}_{2}$ ratio}

All the samples B1-B6 with $\mathrm{C} / \mathrm{S}$ ratio from 1.6 to 2.1 were white. Figure 4 shows their XRD patterns. The sample B5 $(\mathrm{C} / \mathrm{S}=2)$ contained mostly $\beta$-belite (larnite, ICDD 330302) and a small amount of lime (ICDD 821690). Sample B4 $(\mathrm{C} / \mathrm{S}=1.9)$ also included $\mathrm{C}_{3} \mathrm{~S}_{2}$ (rankinite, ICDD 701138), whose content increased (while $\beta$-belite content decreases) with decreasing $\mathrm{C} / \mathrm{S}$ ratio. The rise of the $\mathrm{C} / \mathrm{S}$ ratio above 2 led to the increase in lime content. 
TABLE 6. Chemical composition (wt. \%) of $\beta$-belite samples

\begin{tabular}{lccccccccccc}
\hline Sample & $\mathbf{S i O}_{2}$ & $\mathrm{Al}_{2} \mathbf{O}_{3}$ & $\mathbf{F e}_{2} \mathbf{O}_{3}$ & $\mathbf{C a O}$ & $\mathbf{M g O}$ & $\mathbf{K}_{2} \mathbf{O}$ & $\mathbf{N a}_{2} \mathbf{O}$ & $\mathbf{P}_{2} \mathbf{O}_{5}$ & $\mathbf{Z r O}_{2}$ & $\mathbf{T i O}_{2}$ & $\begin{array}{c}\mathbf{C a O} / \mathbf{S i O}_{2} \\
(\mathbf{m o l} / \mathbf{m o l})\end{array}$ \\
\hline B1 & 38.08 & 0.34 & 0.09 & 56.85 & 0.42 & 3.42 & 0.29 & 0.13 & 0.34 & - & 1.60 \\
B2 & 36.70 & 0.34 & 0.09 & 58.22 & 0.43 & 3.45 & 0.30 & 0.13 & 0.32 & - & 1.70 \\
B3 & 35.41 & 0.34 & 0.08 & 59.50 & 0.44 & 3.47 & 0.30 & 0.12 & 0.31 & - & 1.80 \\
B4 & 34.22 & 0.34 & 0.08 & 60.68 & 0.45 & 3.50 & 0.30 & 0.11 & 0.29 & - & 1.90 \\
B5, B7-B11, B16-B20 & 33.10 & 0.35 & 0.07 & 61.79 & 0.46 & 3.52 & 0.30 & 0.11 & 0.28 & - & 2.00 \\
B6 & 32.06 & 0.35 & 0.07 & 62.83 & 0.47 & 3.54 & 0.30 & 0.10 & 0.26 & - & 2.10 \\
B12 & 32.99 & 0.35 & 0.02 & 61.56 & 1.00 & 3.56 & 0.42 & - & - & 0.01 & 2.00 \\
B13 & 32.53 & 0.34 & 0.07 & 60.74 & 0.45 & 0.11 & 5.37 & 0.10 & 0.27 & - & 2.00 \\
B14 & 34.34 & 0.38 & 0.11 & 64.10 & 0.47 & - & - & 0.16 & 0.40 & - & 2.00 \\
B15 & 33.13 & 0.37 & 0.10 & 61.85 & 0.46 & 3.52 & - & 0.15 & 0.39 & - & 2.00 \\
\hline
\end{tabular}

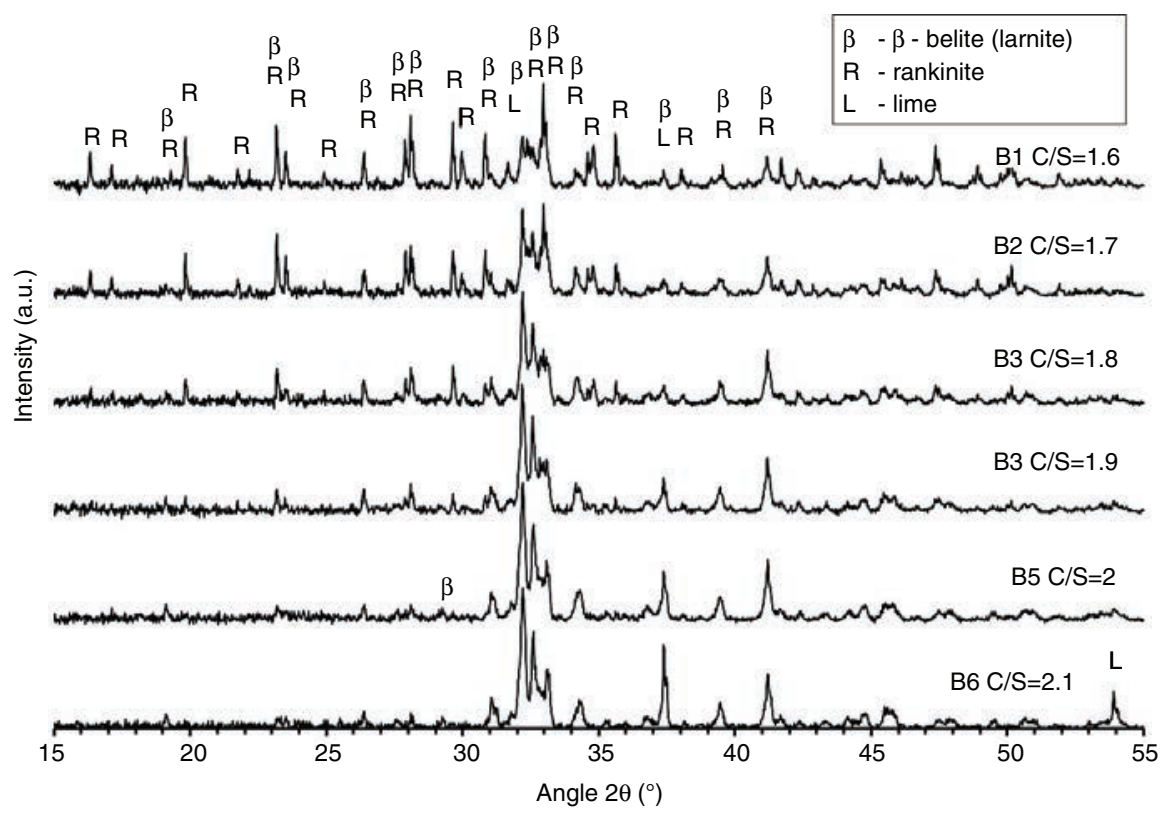

Figure 4. XRD patterns of samples $\mathrm{B} 1-\mathrm{B} 6$ with different $\mathrm{CaO} / \mathrm{SiO}_{2}$ ratio.

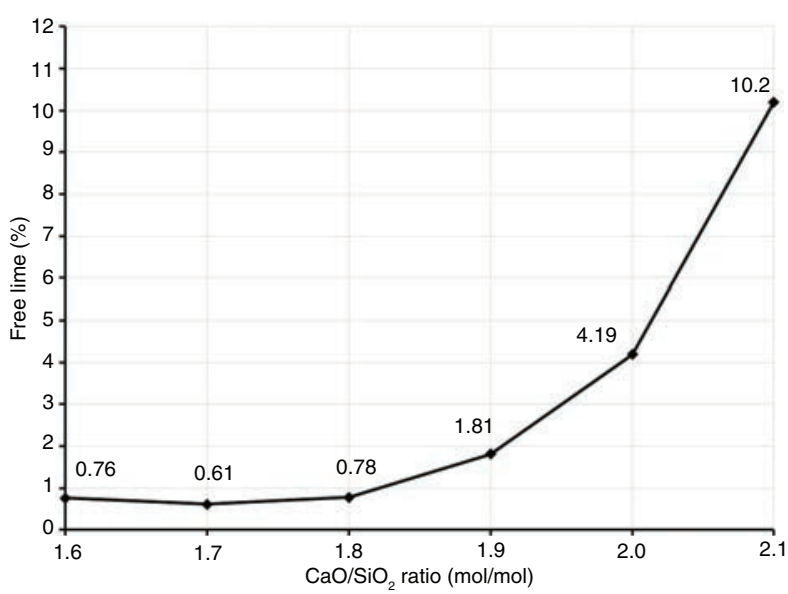

Figure 5. Effect of $\mathrm{CaO} / \mathrm{SiO}_{2}$ ratio on the free lime content.
Free lime assessments (Figure 5) agreed with the results of XRD analysis described above. Free lime content was lower than $1 \%$ up to $\mathrm{C} / \mathrm{S}=1.8$; further increase of $\mathrm{C} / \mathrm{S}$ ratio led to increasing free lime content. When the C/S ratio was 2 , which is the stoichiometric ratio of these components in $\beta$-belite (sample B5), free lime content was $4.19 \%$, which means that approximately $93 \%$ of $\mathrm{CaO}$ was bound.

\subsection{Effect of burning temperature}

The samples B5, B7, B8 were white in colour, while samples B9, B10 were light green. The sample B11 was amorphous green glass, obviously because of the applied temperature $1400{ }^{\circ} \mathrm{C}$, which was higher than the melting point of mixture M5. 


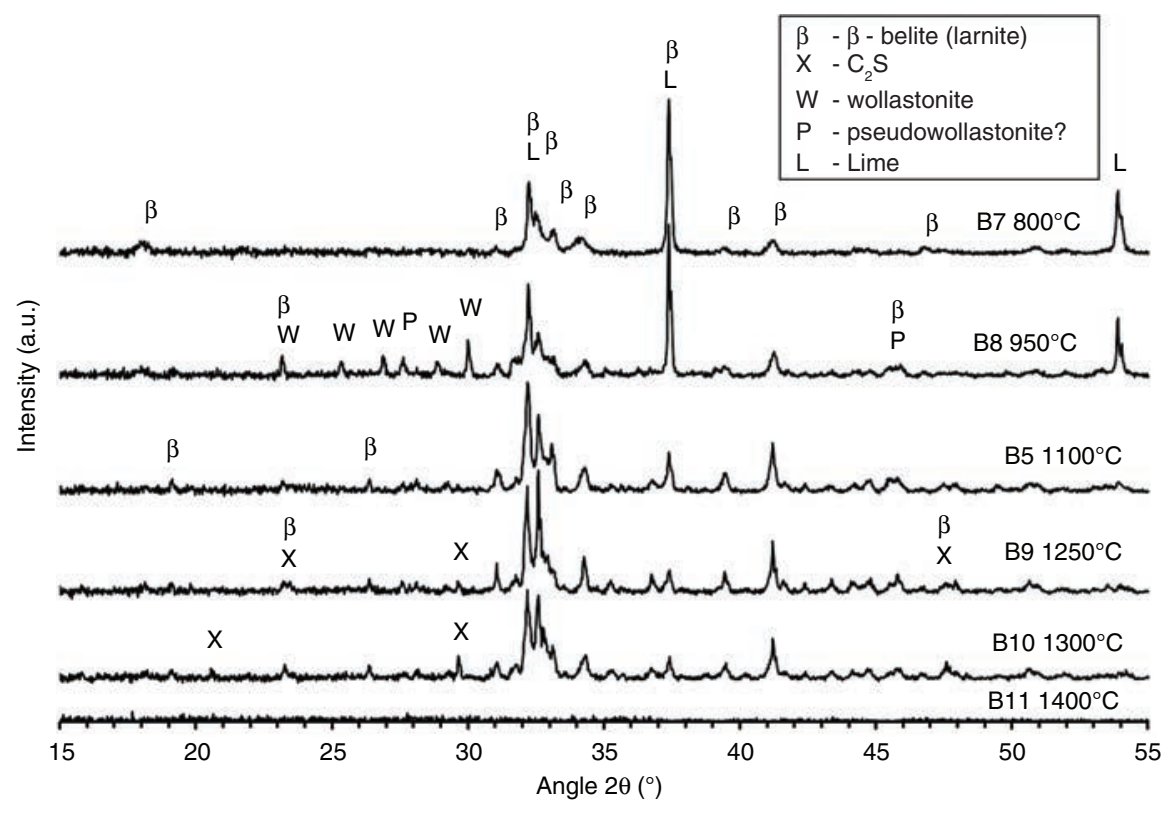

FIGURE 6. XRD patterns of samples B5 and B7-B11 with different burning temperatures.

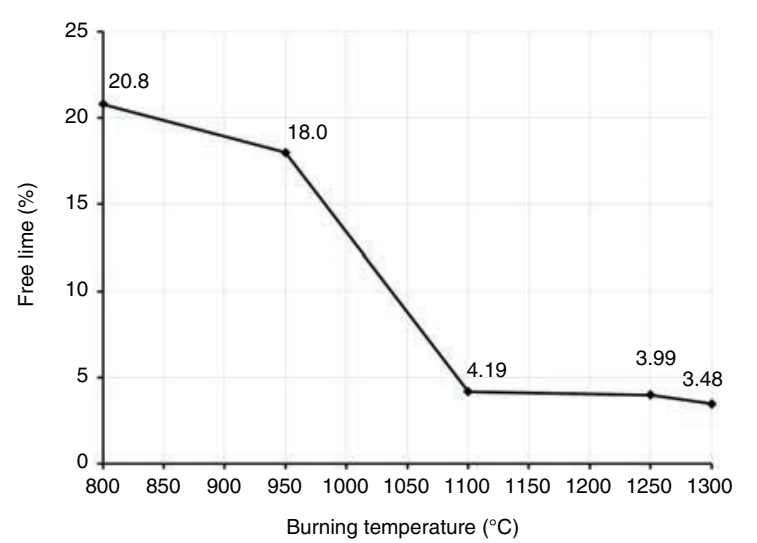

FIGURE 7. Effect of burning temperature on free lime content.

The development of phase composition with burning temperature is shown in Figure 8 . $\beta$-belite was present in all the samples burnt at temperatures from $800{ }^{\circ} \mathrm{C}$ to $1300{ }^{\circ} \mathrm{C}$; its content rose up to $1100^{\circ} \mathrm{C}$, then held at $1300{ }^{\circ} \mathrm{C}$. Another form of dicalcium silicate (ICDD 310297) was formed above $1250{ }^{\circ} \mathrm{C}$. The sample B8, burnt at $950^{\circ} \mathrm{C}$ also contained wollastonite (ICDD 431460) and probably pseudowollastonite (ICDD 896463), while the sample B7 burnt at $800{ }^{\circ} \mathrm{C}$ did not. $\beta$-belite is thus formed either by direct reaction of two molecules of $\mathrm{CaO}$ with an $\mathrm{SiO}_{2}$ molecule (sample B7) or by reacting one molecule $\mathrm{CaO}$ with $\mathrm{CaSiO}_{3}$ (wollastonite, sample B8), which is under certain conditions an intermediate of $\beta$-belite formation. Both of these mechanisms of $\beta$-belite formation were described $(22,44)$ and the presence of wollastonite in the samples of $\beta$-belite or belite cements was documented $(9,22,28,44)$.

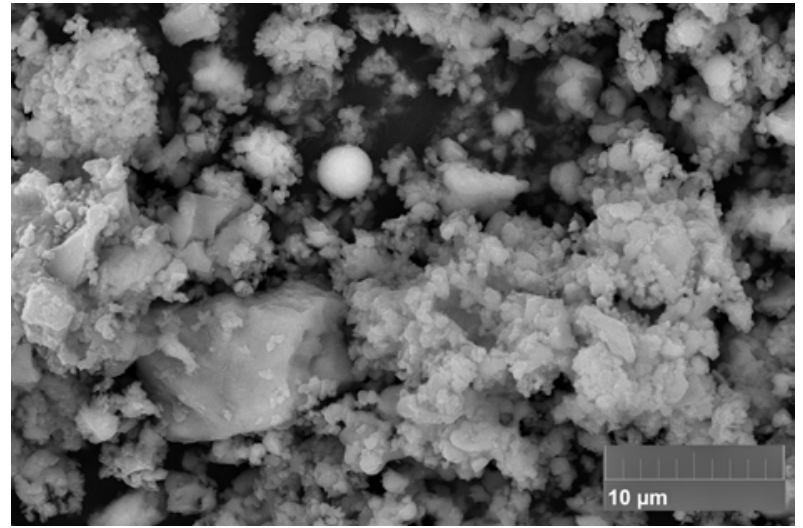

Figure 8. Morphology of sample B8 treated at $950{ }^{\circ} \mathrm{C}$.

The XRD patterns (Figure 6) did not present any $\alpha$-belite and $\gamma$-belite peaks.

The effect of burning temperature on the free lime content is shown graphically in Figure 7. Free lime rapidly diminished to the value $4.19 \%$ up to the temperature $1100{ }^{\circ} \mathrm{C}$. Further temperature increase brought about only moderate decrease in the free lime content.

Typical morphologies of the samples prepared at different temperatures are shown in Figures 8-10.

The samples B7 and B8 are not homogenous. Spherical particles of silica fume are clearly visible in Figure 8. SEM morphologies of the samples B5, B9 and B10 are similar - materials are homogenous and particles are sintered (Figure 9). Figure 15 shows a glassy surface (sample B8), which was formed at temperatures exceeding the melting point of the mixture M5. 


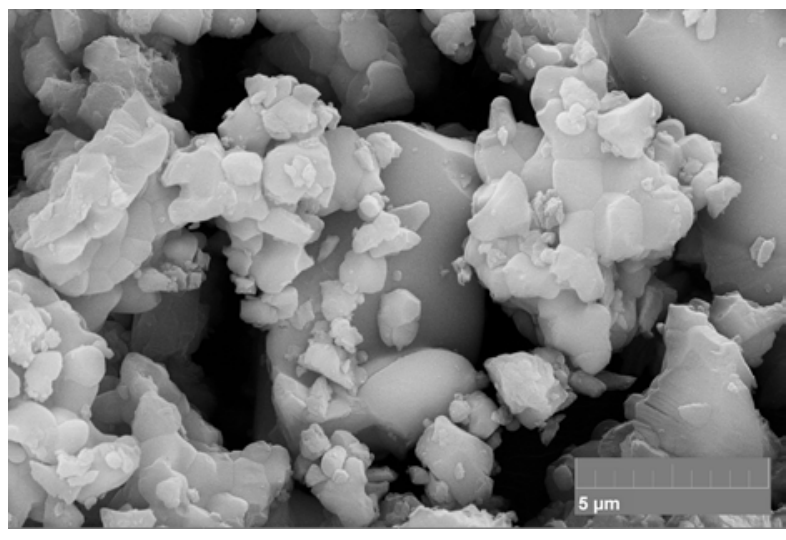

FIGURE 9. Morphology of sample B5 treated at 1100.

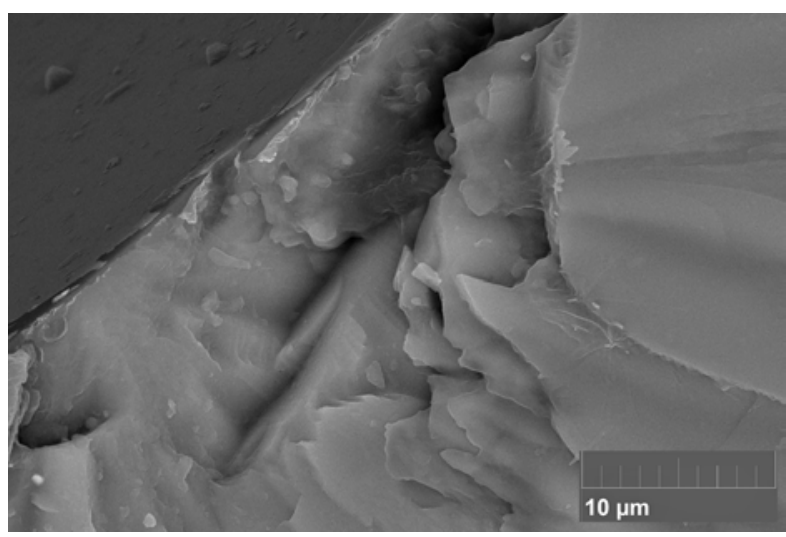

Figure 10. Morphology of sample B11 treated at $1400^{\circ} \mathrm{C}$.

\subsection{Effect of raw materials}

The samples B5 and B12-B15 were prepared from various mixtures of raw materials, but the $\mathrm{C} / \mathrm{S}$ ratio and the calcination procedure were kept the same. XRD patterns of these samples and the results of free lime determination, compared in Figure 11 and Figure 12 show differences in free lime content. The color of the sample B13 was light green, sample B14 was brownish and the rest of the samples were white.

The sample B5, prepared from a mixture of limestone, silica fume and potassium silicate had the lowest content of free lime. The replacement of potassium silicate with sodium silicate (B13) or

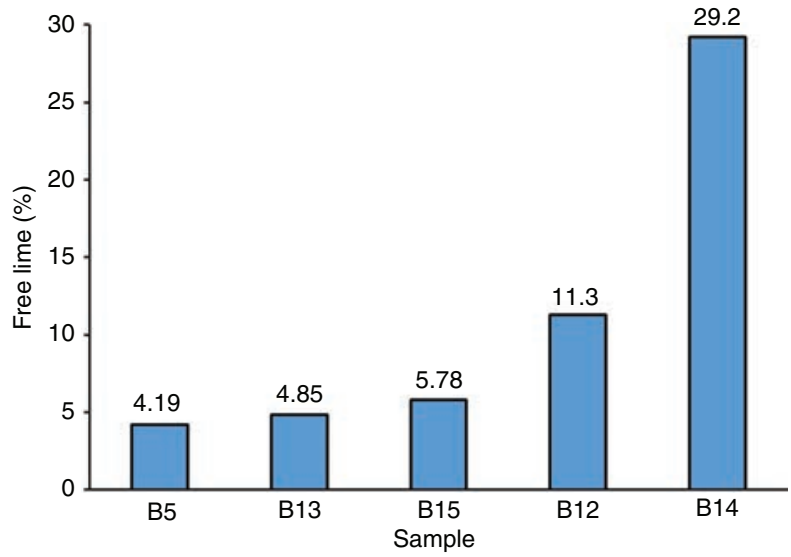

FIGURE 12. Effect of different raw materials utilisation on the free lime content.

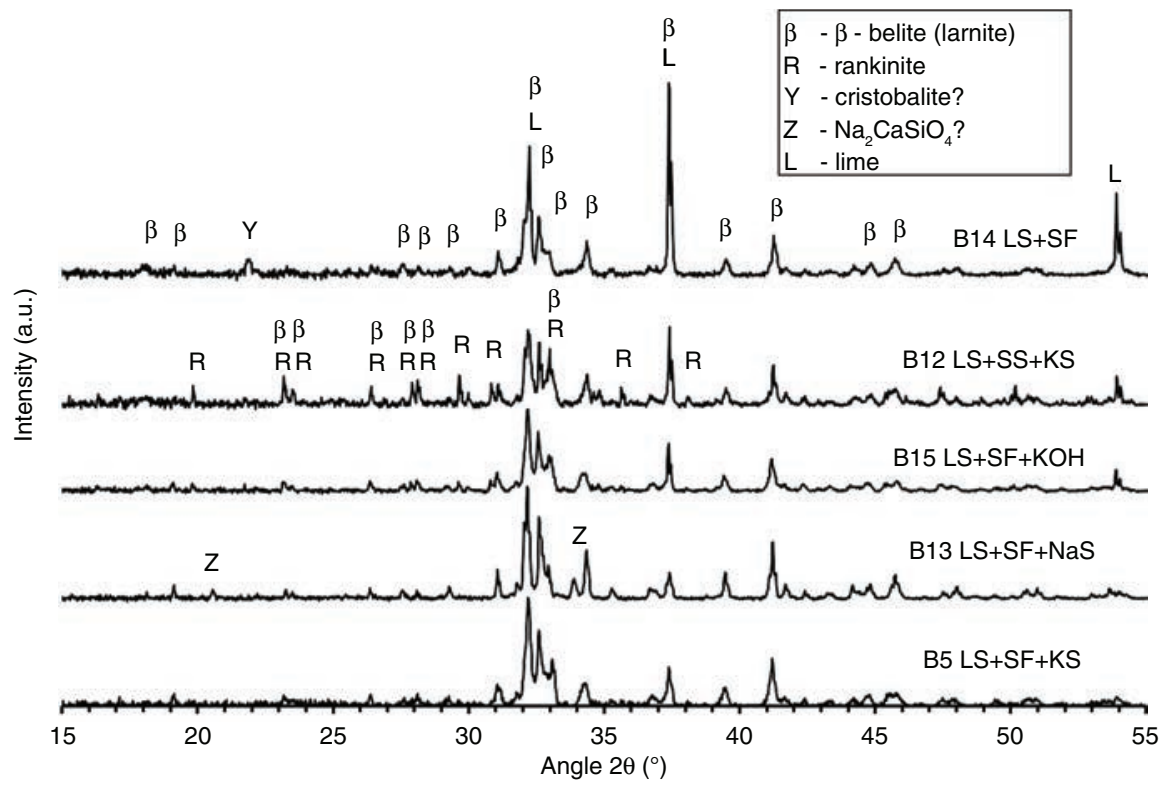

FIGURE 11. XRD patterns of samples B5 and B12-B15 prepared from different raw materials (LS - limestone, SF - silica fume, SS - synthetic silica, KS - potassium silicate, NaS - sodium silicate, $\mathrm{KOH}$ - potassium hydroxide). 


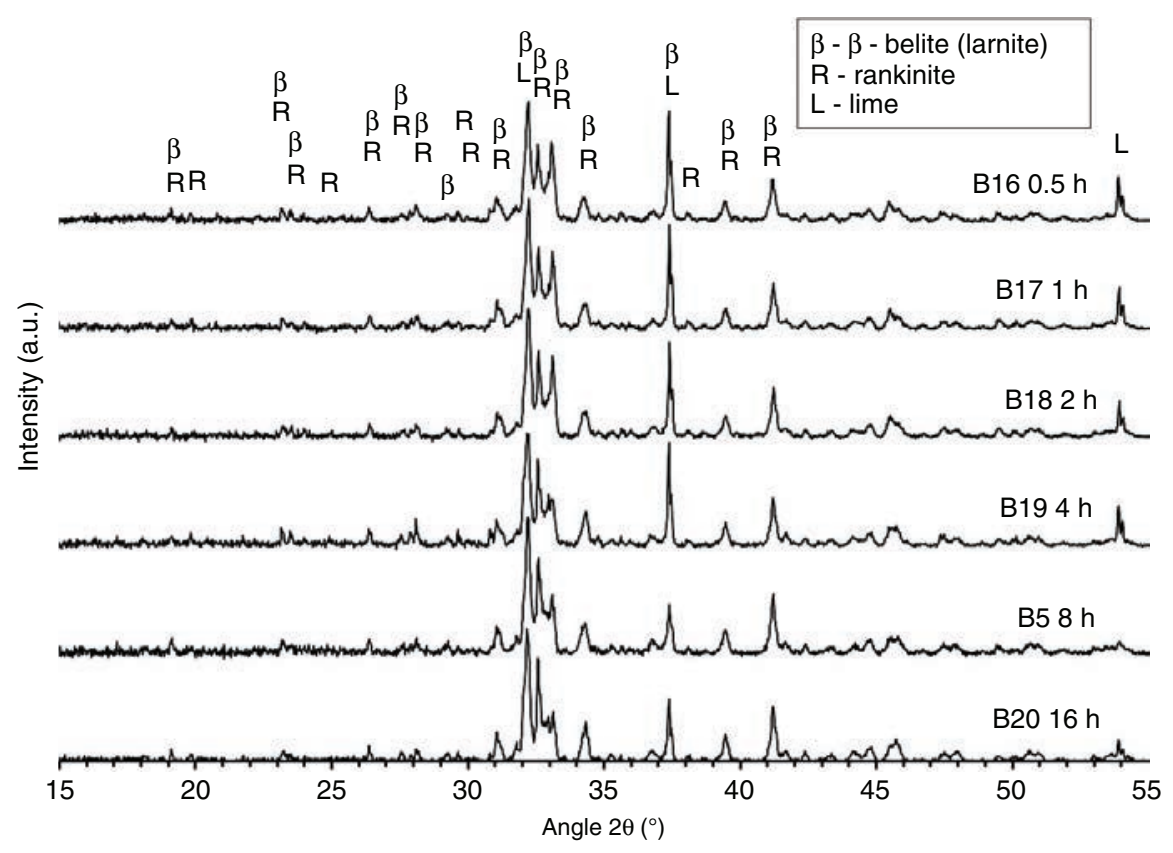

FIGURE 13. XRD patterns of samples B5 and B16-B20 with different burning time.

potassium hydroxide (B15) led to a slight increase in free lime content. A significantly higher increase was caused by the replacement of silica fume with synthetic silica (B12). The highest lime content in the sample B14 demonstrates a significant influence of alkaline ions on the solid-state reaction rate. X-ray diffraction patterns are consistent with the results of free lime determination. All samples contained $\beta$-belite. The samples B15, B12 and B14 contained lime, the amounts of which increased respectively. The sample B13 probably contained sodium calcium silicate (ICDD 731726) and the sample B14 cristobalite (ICDD 391425). The diffraction pattern of the sample B12 explains why it contains more free lime than the sample B5, although synthetic silica has significantly higher specific surface area than silica fume (Table 2). The presence of rankinite in the sample of $\mathrm{B} 12$ indicates a local excess of $\mathrm{SiO}_{2}$ (see Figure 4). The reason for a higher content of free lime in the sample B12 is thus sample inhomogeneity rather than low reactivity of synthetic silica. Synthetic silica is less miscible with other components of the mixture compared to silica fume, due to considerably lower bulk density (Table 2).

\subsection{Effect of burning time}

The samples B5 and B16-B20 were prepared from the same mixture M5 $(\mathrm{C} / \mathrm{S}=2)$ by burning at $1100{ }^{\circ} \mathrm{C}$ for various times $(0.5-16 \mathrm{~h})$. All of these samples were white. The influence of burning time on mineralogical composition and

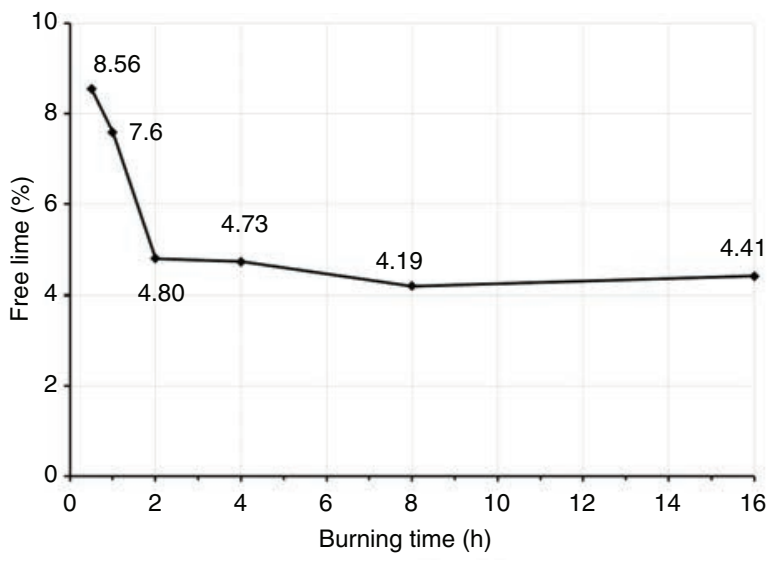

Figure 14. Effect of burning time on free lime content.

free lime content are shown in Figure 13 and Figure 14. All samples contained predominantly $\beta$-belite. The presence of lime and rankinite was clearly visible in the diffraction patterns of samples burned for less than 4 hours. The results of free lime content determination agreed with the results of XRD analysis. Free lime content rapidly decreased within the time of calcination $2 \mathrm{~h}$ to $4.80 \%$. Further prolongation of burning time did not change free lime content significantly. The presence of free lime residues in all samples indicates that the cause was not an excess of lime in the mixture (see Figure 5), neither slow reaction rate (see Figure 7 and Figure 14), but only inhomogeneities in the mixture of raw materials. 


\section{CONCLUSIONS}

$\beta$-belite with low content of free lime (below $5 \%$ ) was prepared by burning a mixture of powdered limestone, silica fume and liquid potassium silicate (water glass) with a ratio $\mathrm{C} / \mathrm{S}=2$ and $\mathrm{K}_{2} \mathrm{O}$ content about 3,5\% at temperatures from 1100 to $1300{ }^{\circ} \mathrm{C}$ for more than $2 \mathrm{~h}$. Increasing $\mathrm{C} / \mathrm{S}$ ratio above 2 led to the an increase in free lime content. Rankinite was formed at a $\mathrm{C} / \mathrm{S}$ ratio under 2 ; its content increased (while $\beta$-belite content decreases) with decreasing $\mathrm{C} / \mathrm{S}$ ratio. A decrease in the burning temperature to $950{ }^{\circ} \mathrm{C}$ resulted in an increase in free lime content and formation of wollastonite - an intermediate of $\beta$-belite formation. Liquid potassium silicate in the reaction mixture was replaced with liquid sodium silicate or potassium hydroxide, without substantial deterioration in $\beta$-belite purity. The replacement of silica fume with synthetic silica with a low bulk density did not prove as expected because of low miscibility with other raw materials.

The described procedure for $\beta$-belite preparation is very simple and uses raw materials produced in large volumes. Therefore, it indicates high potential for industrial application, especially if impurity content is reduced by optimizing the amount of alkali metal in the reaction mixture.

\section{ACKNOWLEDGMENTS}

The author thanks Karol Bayer (Faculty of Restoration, University of Pardubice) for providing SEM pictures.

The publication is a result of the project Development of the UniCRE Centre (project code LO1606) which was financially supported by the Ministry of Education, Youth and Sports of the Czech Republic under the National Sustainability Programme I.

\section{REFERENCES}

1. Gartner, E. (2004) Industrially interesting approaches to "low- $\mathrm{CO}_{2}$ " cements. Cem. Concr. Res. 34 (9), 1489-1498. http://dx.doi.org/10.1016/j.cemconres.2004.01.021

2. Schneider, M.; Romer, M.; Tschudin ,M.; Bolio, H. (2011) Sustainable cement production-present and future. Cem. Concr. Res. 41 (7), 642-650. http://dx.doi.org/10.1016/j. cemconres.2011.03.019

3. Chatterjee, A.K. (1996) High belite cementsPresent status and future technological options: Part I. Cem. Concr. Res. 26 (8), 1213-1225. http://dx.doi. org/10.1016/0008-8846(96)00099-3

4. Bensted, J. (1978) Gamma-dicalcium silicate and its hydraulicity. Cem. Concr. Res. 8 (1), 73-76. http://dx.doi. org/10.1016/0008-8846(78)90059-5

5. Kriskova, L.; Pontikes ,Y.; Zhang, F.; Cizer, Ö.; Jones, P.T.; Van Balen ,K.; Blanpain, B. (2014) Influence of mechanical and chemical activation on the hydraulic properties of gamma dicalcium silicate. Cem. Concr. Res. 55, 59-68. http://dx.doi.org/10.1016/j.cemconres.2013.10.004
6. Rodrigues, F.A. (2003) Synthesis of chemically and structurally modified dicalcium silicate. Cem. Concr. Res. 33 (6), 823-827. http://dx.doi.org/10.1016/S0008-8846(02)01065-7.

7. Kurdowski, W.; Duszak, S.; Trybalska, B. (1997) Belite produced by means of low-temperature synthesis. Cem. Concr. Res. 27 (1), 51-62. http://dx.doi.org/10.1016/ S0008-8846(96)00198-6

8. Kacimi, L.; Simon-Masseron ,A.; Salem, S.; Ghomari, A.; Derriche, Z. (2009) Synthesis of belite cement clinker of high hydraulic reactivity. Cem. Concr. Res. 39 (7), 559-565. http://dx.doi.org/10.1016/j.cemconres.2009.02.004

9. Pimraksa, K.; Hanjitsuwan, S.; Chindaprasirt, P. (2009) Synthesis of belite cement from lignite fly ash. Ceram. Int. 35(6), 2415-2425. http://dx.doi.org/10.1016/j.ceramint.2009.02.006

10. Morsli, K.; De la Torre, A.G.; Cuberos, A.J.M.; Zahir, M.; Aranda, M.A.G. (2009) Preparation and characterization of alkali-activated white belite cements. Mater. Construcc. 59 (294), 19-29. http://dx.doi.org/10.3989/mc.2009.44307

11. Morsli, K.; De la Torre, A.G.; Stöber, S.; Cuberos, A.J.M.; Zahir, M.; Aranda, M.A.G. (2007) Quantitative Phase Analysis of Laboratory-Active Belite Clinkers by Synchrotron Powder Diffraction. J. Am. Ceram. Soc. 90 (10), 3205-3212. http://dx.doi. org/10.1111/j.1551-2916.2007.01870.x

12. Chen, Y.L.; Lin, Ch.J.; Ko, M.S.; Lai, Y.Ch.; Chang, J.E. (2011) Characterization of mortars from belite-rich clinkers produced from inorganic waste. Cem. Concr. Comp. 33 (2), 261-266. http://dx.doi.org/10.1016/j.cemconcomp.2010.10.012

13. Zivica, V. (2000) Properties of blended sulfoaluminate belite cement. Constr. Build. Mater. 14 (8), 433-437. http:// dx.doi.org/10.1016/S0950-0618(00)00050-7

14. Glasser, F.P.; Zhang, L. (2001) High-performance cement matrices based on calcium sulfoaluminate-belite compositions. Cem. Concr. Res. 31 (12), 1881-1886. http://dx.doi. org/10.1016/S0008-8846(01)00649-4

15. Strigac J.; Palou M. T.; Kristin J.; Majling J. (2000) Morphology and chemical composition of minerals inside the phase assemblage $\mathrm{C}-\mathrm{C}_{2} \mathrm{~S}-\mathrm{C}_{4} \mathrm{~A}_{3} \overline{\mathrm{S}}-\mathrm{C}_{4} \mathrm{AF}-\mathrm{C} \overline{\mathrm{S}}$ relevant to sulphoaluminate belite cements. Ceramics-Silikáty 44 (1), 26-34.

16. Martín-Sedeno, M.C.; Cuberos A.J.M.; De la Torre, A.G.; Álvarez-Pinazo, G.; Ordónez, L.M.; Gateshki, M.; Aranda, M.A.G. (2010) Alluminum-rich belite sulfoaluminate cements: Clinkering and early age hydration. Cem. Concr. Res. 40 (3), 359-369. http://dx.doi.org/10.1016/j. cemconres.2009.11.003

17. Tišlova, R.; Kozłowska, A.; Kozłowski, R.; Hughes, D. (2009) Porosity and specific surface area of Roman cement pastes. Cem. Concr. Res. 39 (10), 950-956. http://dx.doi. org/10.1016/j.cemconres.2009.06.020

18. Hughes, D.C.; Jaglin, D.; Kozłowski, R.; Mucha, D. (2009) Roman cements - Belite cements calcined at low temperature. Cem. Concr. Res. 39 (2), 77-89. http://dx.doi. org/10.1016/j.cemconres.2008.11.010

19. Gosselin, C.; Verges-Belmin, V.; Royer, A.; Martinet, G. (2009) Natural cement and monumental restoration. Mater. Struct. 42 (6), 749-763. http://dx.doi.org/10.1617/ s11527-008-9421-7

20. Starinieri, V.; Hughes ,D.C.; Gosselin, C.; Wilk, D.; Bayer, K. (2013) Pre-hydration as a technique for the retardation of Roman cement mortars. Cem. Concr. Res. 46, 1-13. http://dx.doi.org/10.1016/j.cemconres.2013.01.004

21. Weber, J.; Gadermayr, N.; Kozłowski, R.; Mucha, D.; Hughes, D.; Jaglin, D.; Schwarz, W. (2007) Microstructure and mineral composition of Roman cements produced at defined calcination conditions. Mater. Char. 58 (11-12), 1217-1228. http://dx.doi.org/10.1016/j.matchar.2007.04.025

22. El-Didamony, H.; Khalil, Kh.A.; Ahmed, I.A.; Heikal, M. (2012) Preparation of $\beta$-dicalcium silicate $\left(\beta-C_{2} S\right)$ and calcium sulfoaluminate $\left(\mathrm{C}_{3} \mathrm{~A}_{3} \overline{\mathrm{CS}}\right)$ phases using nontraditional nano-materials. Constr. Build. Mater. 35 77-83. http://dx.doi.org/10.1016/j.conbuildmat.2012.02.064

23. Ozturk, A.; Suyadal, Y.; Oguz, H. (2000) The formation of belite phase by using phosphogypsum and oil shale. Cem. Concr. Res. 30 (6), 967-971. http://dx.doi.org/10.1016/ S0008-8846(00)00262-3 
24. Staněk, T.; Sulovsky, P. (2015) Active low-energy belite cement. Cem. Concr. Res. 68, 203-210. http://dx.doi. org/10.1016/j.cemconres.2014.11.004

25. Gies, A.; Knofel ,D. (1986) Influence of alkalies on the composition of belite-rich cement clinkers and the technological properties of the resulting cements. Cem. Concr. Res. 16 (3), 411-422. http://dx.doi.org/10.1016/0008-8846(86)90117-1

26. Rodrigues, F.A. (2003) Low-temperature synthesis of cements from rice hull ash. Cem. Concr. Res. 33 (10), 1525-1529. http://dx.doi.org/10.1016/S0008-8846(03)00104-2

27. Mazouzi, W.; Kacimi, L.; Cyr M.; Clastres P. (2014) Properties of low temperature belite cements made from aluminosilicate wastes by hydrothermal method. Cem. Concr. Comp. 53, 170-177. http://dx.doi.org/10.1016/j. cemconcomp.2014.07.001

28. Maheswaran, S.; Kalaiselvam, S.; Saravana Karthikeyan, S.K.S.; Kokila, C.; Palani, G.S. (2016) $\beta$-Belite cements ( $\beta$-dicalcium silicate) obtained from calcined lime sludge and silica fume. Cem. Concr. Comp. 66, 57-65. http:// dx.doi.org/10.1016/j.cemconcomp.2015.11.008

29. Campillo, I.; Guerrero, A.; Dolado, J.S.; Porro, A.; Ibáñez, J.A.;Goñi, S. (2007) Improvement of initial mechanical strength by nanoalumina in belite cements. Materials Letters 61 (8-9), 1889-1892. http://dx.doi.org/10.1016/j. matlet.2006.07.150

30. Guerrero, A. Goñi, S; Macias, A; Luxan, M.P. (2000) Effect of the starting fly ash on the microstructure and mechanical properties of fly ash-belite cement mortars. Cem. Concr. Res. 30 (4), 553-559. http://dx.doi.org/10.1016/ S0008-8846(00)00198-8

31. Kacimi ,L.; Cyr, M.; Clastres, P. (2010) Synthesis of $\alpha_{L^{-}}^{\prime}$ $\mathrm{C}_{2} \mathrm{~S}$ cement from fly-ash using the hydrothermal method at low temperature and atmospheric pressure. J. Hazard. Mater. 181 (1-3), 593-601. http://dx.doi.org/10.1016/j. jhazmat.2010.05.054

32. Singh, N.B. (2006) Hydrothermal synthesis of $\beta$-dicalcium silicate $\left(\beta-\mathrm{Ca}_{2} \mathrm{SiO}_{4}\right)$. Progress in crystal growth and characterization of materials 52 (1-2) 77-83. http://dx.doi. org/10.1016/j.pcrysgrow.2006.03.011

33. Link, T; Bellmann ,F; Ludwig, H.M.; Ben Haha, M. (2015) Reactivity and phase composition of $\mathrm{Ca}_{2} \mathrm{SiO}_{4}$ binders made by annealing of alpha-dicalcium silicate hydrate. Cem. Concr. Res. 67, 131-137. http://dx.doi.org/10.1016/j. cemconres.2014.08.009
34. Guerrero ,A.; Goñi, S.; Macias, A. (2000) Durability of new fly ash-belite cement mortars in sulfated and chloride medium. Cem. Concr. Res. 30 (8), 1231-1238. http://dx.doi. org/10.1016/S0008-8846(00)00313-6

35. Guerrero, A.; Goñi, S.; Macias, A.; Luxan, M.P. (1999) Hydraulic activity and microstructural characterization of new fly ash-belite cements synthesized at different temperatures. J. Mater. Res. 14 (6), 2680-2687. http://dx.doi. org/10.1557/JMR.1999.0359

36. Garbev, K.; Beuchle, G.; Schweike, U.; Merz, D.; Dregert, O.; Stemmermann P. (2014) Preparation of a Novel Cementitious Material from Hydrothermally Synthesized C-S-H Phases. J. Am. Ceram. Soc. 97 (7), 2298-2307. http:// dx.doi.org/10.1111/jace. 12920

37. Gou, Z,.; Chang, J. (2004) Synthesis and in vitro bioactivity of dicalcium silicate powders. J. Eur. Ceram. Soc. 24 (1), 93-99. http://dx.doi.org/10.1016/S0955-2219(03)00320-0

38. Stephan, D.; Wilhelm, P. (2004) Synthesis of Pure Cementitious Phases by Sol-Gel Process as Precursor. Z. Anorg. Allg. Chem. 630 (10), 1477-1483. http://dx.doi. org/10.1002/zaac. 200400090

39. Gou, Z.; Chang, J.; Zhai, W.; Wang, J. (2005) Study on the Self-Setting Property and the In Vitro Bioactivity of $\beta-\mathrm{Ca}_{2} \mathrm{SiO}_{4}$. J. Biomed. Mater. Res. B Appl. Biomater. 73 (2), 244-251. http://dx.doi.org/10.1002/jbm.b.30203

40. Chrysafi, R.; Perraki, Th.; Kakali, G. (2007) Sol-gel preparation of $2 \mathrm{CaO} \cdot \mathrm{SiO}_{2}$. J. Eur. Ceram. Soc. 27 (2-3), 1707-1710. http://dx.doi.org/10.1016/j.jeurceramsoc.2006. 05.004

41. Nettleship, I.; Shull, J.L.; Kriven, W. M. (1993) Chemical preparation and phase stability of $\mathrm{Ca}_{2} \mathrm{SiO}_{4}$ and $\mathrm{Sr}_{2} \mathrm{SiO}_{4}$ powders. J. Eur. Ceram. Soc. 11 (4), 291-298. http://dx.doi. org/10.1016/0955-2219(93)90028-P

42. Dovál, M.; Palou, M.; Kovár, V. (2006) Hydration and microstructure of binder compounds containing $\mathrm{C}_{2} \mathrm{AS}$ and $\mathrm{C}_{2} \mathrm{~S}$ synthesized by sol-gel method. Ceramics-Silikáty 50 (2), 106-114.

43. Hong, S.H.; Young, J.F. (1999) Hydration kinetics and phase stability of dicalcium silicate synthesized by the Pechini process. J. Am. Ceram. Soc. 82 (7), 1681-1686.

44. Zeng, L.; Li, Z. (2014) Solubility of dicalcium silicate in the $\mathrm{NaOH}-\mathrm{NaAl}(\mathrm{OH})_{4}-\mathrm{Na}_{2} \mathrm{CO}_{3}$ solutions: Determination and prediction. Hydrometallurgy 147, 127-133. http:// dx.doi.org/10.1016/j.hydromet.2014.05.007 